\title{
A Reestruturação do Setor Público Estatal Brasileiro rumo às Privatizações dos anos 1990
}

Monica Piccolo Almeida*

Resumo: Este trabalho tem como objetivo principal analisar os mecanismos que desencadearam a profunda crise das Empresas Estatais (EEs) brasileiras ao longo dos anos 1980 abrindo espaço, assim, para o fortalecimento do projeto privatista implementado com grande força nos anos 1990. Parte-se da hipótese central que os principais argumentos privatistas capitaneados na década 1990 não se sustentam empiricamente. Assim, o quadro de falência econômica das EEs teria sido lentamente gestado a partir da política econômica posta em vigor nos anos 1970, principalmente a partir do II Plano Nacional de Desenvolvimento de 1974. Para a operacionalização da hipótese aqui construída, serão investigados os principais marcos jurídicos do projeto privatista implementados ainda durante a Ditadura Empresarial Militar, os relatórios do Conselho Federal de Desestatização e do Banco Nacional de Desenvolvimento Social (BNDES), principal gestor do programa de desestatização.

Palavras-chave: Privatização. Empresas Estatais. Política Econômica.

\footnotetext{
* Professora Adjunta I da Universidade Estadual do Maranhão. Coordenadora do Núcleo de Pesquisa em História Contemporânea (NUPEHIC). O artigo apresentado faz parte do projeto Governo Collor e a Consolidação do Neoliberalismo no Brasil (1989-1992) financiado pela Fundação de Amparo à Pesquisa e ao Desenvolvimento Científico e Tecnológico do Maranhão (FAPEMA). E-mail: monica. piccolo@uol.com.br.
} 


\section{Introdução}

O texto que agora se inicia ocupar-se-á da trajetória da política econômica brasileira implementada ao longo dos anos 1970 e 1980 que abriu o caminho para a elaboração e execução da agenda neoliberal nos anos noventa do século passado. A hipótese central aqui postulada repousa na defesa da fragilidade empírica do principal argumento que sustentou o discurso privatista: a situação de crise das Empresas Estatais como fruto de sua inoperância administrativa, da incompetência de sua burocracia e da sangria que promovia nos cofres públicos.

Sustenta-se aqui que o quadro de crise das Empresas Estatais nos anos 1990 encontra-se diretamente relacionado às diretrizes da política econômica das duas décadas anteriores. Como corolário da opção pela execução de políticas pouco realistas de preços dos produtos e da utilização dessas empresas estatais não só como captadoras de créditos externos, mas também como elementos fundamentais de contenção da inflação, desencadeou-se um intenso processo de descapitalização das Empresas Estatais.

\section{A Reestruturação do Setor Público Estatal}

Os momentos finais da Ditadura Empresarial Militar ${ }^{1}$ foram assolados não só pelas questões em torno da transição política, como também, e principalmente, pelos embates em torno da condução da política econômica. Ao cenário de aprovação da anistia ${ }^{2}$, somaram-se as tentativas governamentais de reeditar o sucesso econômico da época do "milagre" 3" (1968-1973) como forma de sustentar politicamente o processo de abertura. A revogação dos atos institucionais, incluindo o mais discricionário entre eles, o Ato Institucional $n^{\circ} 5^{4}$ retirou do governo um de seus principais instrumentos de poder. Assim, diferentemente de outros momentos da Ditadura Empresarial Militar, em que as medidas de uma política econômica extremamente recessiva ${ }^{5}$ foram sustentadas pela liberdade conferida ao governo e à equipe econômica pelos poderes arbitrários garantidos pelos Atos Institucionais, os 
membros do Governo Figueiredo tiveram que lidar com os novos canais de participação da sociedade civil e com o fortalecimento político dos partidos de oposição. As medidas recessivas, por exemplo, no que se referem à política salarial, não mais poderiam ser impostas sem que vozes de oposição fossem ouvidas. No contexto de liberalização da censura e da abertura política, explodem as combativas greves do sindicalismo do ABC paulista, já nos primeiros momentos do governo Figueiredo. Entre janeiro e outubro de 1979, mais de 400 greves eclodiram nas grandes cidades. Os conflitos trabalhistas, assim, assumiram grande proporção.

Nessa conjuntura de efervescência social e de acentuados embates políticos, a composição do Ministério do governo Figueiredo foi marcada pela tentativa de reedição da prosperidade anterior: duas de suas mais importantes figuras eram egressas do Governo Geisel. O novo Ministro do Planejamento, Mário Henrique Simonsen, havia sido, na gestão anterior, Ministro da Fazenda; Karlos Rischbiter, agora na pasta da Fazenda, havia sido, no período entre fevereiro de 1977 e março de 1979, Presidente do Banco do Brasil. A mais destacada continuidade, entretanto, concentra-se na figura de Delfim Neto, o czar da economia brasileira durante o período de 1967 e 1974. Embora tenha assumido como Ministro da Agricultura, o poder político que possuía em função não só de sua presença nos governos militares anteriores e, principalmente, o papel que desempenhou na condução da economia brasileira durante o "milagre", representavam uma possibilidade de constante contraponto ao projeto econômico defendido por Simonsen, centrado nas reformas de caráter recessivo.

A necessidade e urgência do pacote de medidas recessivas, na perspectiva do Ministro de Planejamento, fortaleceram-se com as mudanças no cenário econômico internacional desencadeadas pelo segundo choque de petróleo (1979), responsável pela duplicação dos preços do petróleo e, principalmente, pela elevação dos juros internacionais que promoveu o aumento exponencial dos custos da dívida externa brasileira. Ao aumento dos juros, seguiu-se, também, a maior dificuldade de acesso ao fluxo internacional de capital. Os credores, a partir de então, não estavam mais dispostos a liberar pesadas quantias de investimentos sem a exigência de ajustes nos custos internos a curto 
prazo. Assim, para Simonsen, estava construído o pano de fundo que justificaria e tornava necessário o pacote de medidas recessivas, único caminho possível para garantir o equilíbrio do balanço de pagamentos. O recém-empossado governo, entretanto, não estava disposto a arcar com os custos políticos de tais medidas. As críticas ao pacote recessivo vieram de todos os lados: os empresários debatiam-se contra a elevação dos custos do financiamento; os trabalhadores opunham-se às perdas salariais; as Empresas Estatais faziam campanha contra os baixos níveis de investimento. No primeiro escalão do governo, o Ministro da Fazenda não apoiava a proposta de Simonsen. Mais do que tudo, havia a figura do Ministro da Agricultura que alardeava, para quem quisesse ouvir, que havia uma alternativa à política recessiva. Acabou prevalecendo a tentativa de recuperar as bases do "milagre econômico". Menos de cinco meses depois de sua posse, Simonsen entrega a pasta do Planejamento. Estava aberto o caminho para o retorno do czar da economia. A política recessiva cedeu lugar, pelo menos em um primeiro momento, à política do "crescimento a qualquer custo".

O processo de "reestruturação do setor público" teve início em julho de 1979, com a instituição do Programa Nacional de Desburocratização (Decreto no 83.740/79) e da Secretaria Especial de Controle das Empresas Estatais (SEST). Destinado a dinamizar e simplificar o funcionamento da Administração Pública Federal (art. $1^{\circ}$.), o Programa ficou sob direção do Presidente da República com a assistência do Ministro Extraordinário, Helio Beltrão - que havia ocupado o cargo de Ministro do Planejamento durante o Governo Costa e Silva -, a quem coube orientar e coordenar sua execução (art. $2^{\circ}$.).

O Programa Nacional de Desburocratização (PND), partindo do diagnóstico de ineficiência dos serviços públicos, propunha-se a "contribuir para a melhoria do atendimento dos usuários" (art. $3^{\circ}$.). Ao mesmo tempo, o Governo passa a publicizar o discurso de gigantismo do Estado e do peso da intervenção estatal sobre as atividades que deveriam estar sob o controle da iniciativa privada. Assim sendo, propõe-se a "[...] reduzir a interferência do Governo na atividade do cidadão e do empresário e abreviar a solução dos casos em que essa interferência é necessária, mediante a descentralização das 
decisões, a simplificação do trabalho administrativo e a eliminação de formalidades e exigências cujo custo econômico ou social seja superior ao risco" (art. $3^{\circ}$. 'b).

Ainda nessa mesma perspectiva de redução da intervenção estatal e de dinamização da iniciativa privada, o PND também se propunha a "[...] fortalecer o sistema de livre empresa, favorecendo a empresa pequena e média, que constituem a matriz do sistema, e consolidando a grande empresa privada nacional, para que ela se capacite, quando for o caso, a receber encargos e atribuições que se encontram hoje sob a responsabilidade de empresas do Estado" (art. $3^{\circ}$. 'f).

Nesse redimensionamento do peso e do tamanho do Estado defendido a partir de então, apresentam-se três questões de extrema relevância que ao longo dos anos noventa assumiram papel central na agenda pública: a parceria público-privado; a redução das empresas estatais e, principalmente, a transferência do controle dessas empresas para o setor privado. Assim sendo, o Programa pretendia “[...] impedir o crescimento desnecessário da máquina administrativa federal, mediante o estímulo à execução indireta, utilizando-se, sempre que praticável, o contrato com empresas privadas capacitadas e o convênio com órgãos estaduais e municipais". Ao mesmo tempo, "[...] velar pelo cumprimento da política de contenção da criação indiscriminada de empresas públicas, promovendo o equacionamento dos casos em que for possível e recomendável a transferência do controle para o setor privado, respeitada a orientação do Governo na matéria" (art. $3^{\circ}$.).

No início do Governo Figueiredo, todavia, as críticas à atuação das Empresas Estatais eram diferentes daquelas que se constituíram posteriormente. $\mathrm{O}$ ponto em discussão não era, naquele momento, o questionamento da eficiência do setor público produtivo. O principal objetivo da legislação que começava a se impor era o de regulamentar a desaceleração da expansão do setor produtivo estatal, uma vez que as empresas estatais eram consideradas como fora de controle das autoridades federais (PINHEIRO, 1991, p.13).

Dois anos após a edição do decreto $\mathrm{n}^{\mathrm{o}}$ 83.740, o governo edita novos decretos e, agora, já em defesa aberta e detalhada do processo de privatização. $\mathrm{O}$ decreto $\mathrm{n}^{\text {o. }} 86.215$, de quinze de julho 
de 1981, “[...] fixa normas para a transferência, transformação e desativação de empresas sob o controle do Governo Federal". Esse é, sem sombra de dúvida, o primeiro instrumento legal de normatização das privatizações no Brasil.

Os principais argumentos em defesa da privatização que ( estarão presentes nos dispositivos legais dos demais governos

(O) brasileiros têm aqui seu ponto de origem. Em primeiro lugar, o (m) Governo transfere à iniciativa privada a organização e exploração das atividades econômicas. Os objetivos dos agentes que então controlavam as principais agências estatais passam a ser o fortalecimento do sistema de livre empresa e a consolidação da grande empresa privada nacional. As empresas estatais não só devem ter seu crescimento controlado, mas, quando recomendável, a própria transferência do seu controle para o setor privado. O propósito passa a ser, então, promover a privatização do controle das Empresas Estatais.

A despeito da estrutura legal que começa a ser então construída pelo decreto $\mathrm{n}^{\mathrm{o}}$ 86.215, ainda era muito lento o ritmo em que o processo de privatização vinha ocorrendo. A principal justificativa apresentada era a dificuldade de estabelecer não só os critérios de enquadramento das empresas como também de seus mecanismos e procedimentos de transferência, transformação ou desativação. Assim sendo, para agilizar o processo de privatização, fora estabelecido o prazo de sessenta dias para que o Ministro Chefe da Secretaria de Planejamento da República, Delfim Neto, o Ministro da Fazenda, Ernani Galvêas, e o Ministro Extraordinário para a Desburocratização, Hélio Beltrão,

[...] elaborassem a relação das empresas privadas que, tendo sido criadas pelo setor privado, passaram ulteriormente para o controle direto ou indireto da União, em decorrência de inadimplência de obrigações, excussão de garantia ou situações jurídicas semelhantes (art. $3^{\circ}$. S I). 
Nos anos 1980, estariam enquadradas entre as empresas passíveis de privatização aquelas instituídas pelo Poder Público que tivessem correlatas no setor privado e nacional em condições suficientemente desenvolvidas para exercer as atividades (art. $3^{\circ}$. S II). Ou ainda, as subsidiárias das empresas instituídas ou controladas diretamente ou indiretamente pela União, cuja existência não seja indispensável à execução dos objetivos essenciais da empresa controladora que viesse incorrendo "em desnecessária ou injusta competição com as empresas privadas nacionais" (art. $3^{\circ}$. \ III).

Para conduzir o processo de privatização, foi criada a Comissão Especial de Desestatização. Foram assim identificadas cento e quarenta empresas estatais prontas para serem privatizadas a curto prazo. Dessas, cinquenta foram inicialmente listadas para venda (PINHEIRO, 1991 p. 14). Entretanto, apenas vinte empresas seriam vendidas a agentes privados, conforme quadro a seguir. 
A Reestruturação do Setor Público Estatal Brasileiro...

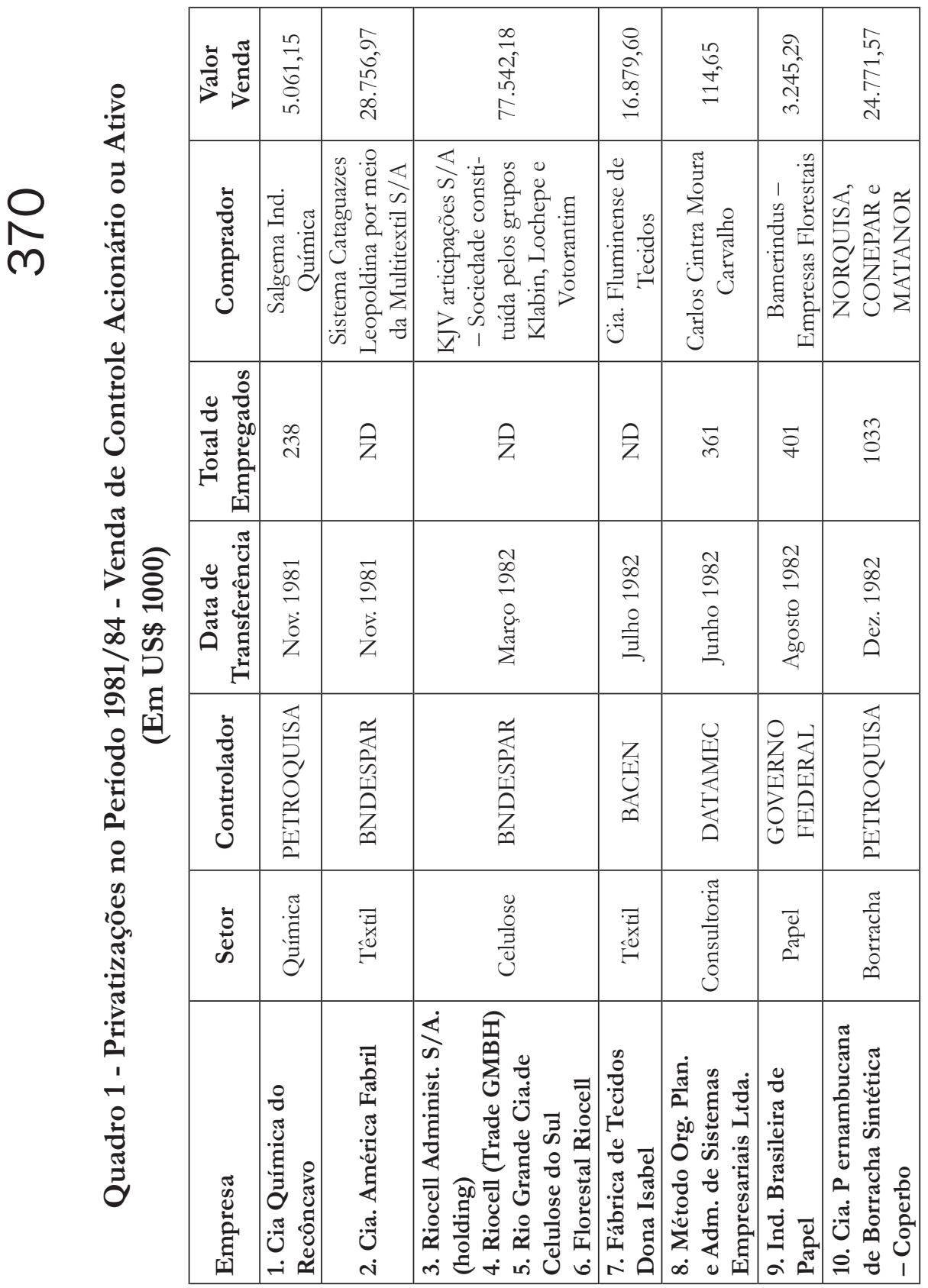

Anos 90, Porto Alegre, v. 21, n. 39, p. 363-397, jul. 2014 
Monica Piccolo Almeida

\begin{tabular}{|c|c|c|c|c|c|c|c|}
\hline $\begin{array}{l}0 \\
+ \\
\text { in } \\
\text { ம் } \\
\dot{0}\end{array}$ & $\begin{array}{l}\stackrel{+}{2} \\
\stackrel{2}{0} \\
\stackrel{1}{n}\end{array}$ & $\begin{array}{l}\infty \\
\stackrel{n}{n} \\
\stackrel{n}{n}\end{array}$ & $\begin{array}{l}0 \\
+ \\
2 \\
\infty \\
\infty \\
10 \\
1\end{array}$ & $\begin{array}{l}\stackrel{0}{a} \\
\text { ñ } \\
\vdots \\
i \\
\text { i }\end{array}$ & $\begin{array}{l}\vec{N} \\
\stackrel{\infty}{\sim}\end{array}$ & $\begin{array}{c}8 \\
0 \\
\text { i }\end{array}$ & 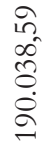 \\
\hline 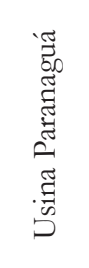 & 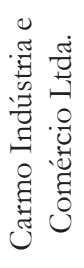 & 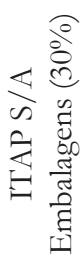 & 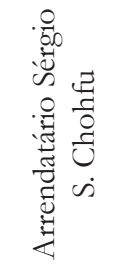 & $\begin{array}{l}\varangle \\
\infty \\
ن \\
\infty \\
0 \\
0\end{array}$ & 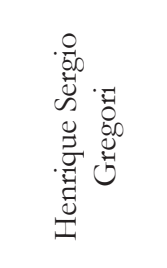 & 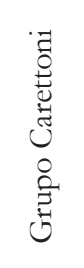 & \\
\hline $\begin{array}{l}\stackrel{0}{\mathrm{n}} \\
\stackrel{1}{n}\end{array}$ & $\vec{\infty}$ & 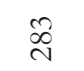 & $\hat{\sigma}$ & $\infty$ & ๙ & $\stackrel{\llcorner}{\sim}$ & ষ্ঠ \\
\hline 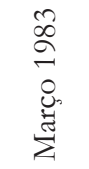 & 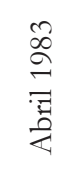 & 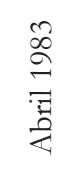 & 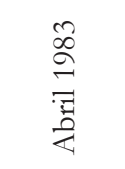 & 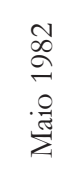 & $\begin{array}{l}+ \\
2 \\
2 \\
= \\
= \\
\frac{7}{4}\end{array}$ & $\begin{array}{l}+\infty \\
\stackrel{\infty}{=}\end{array}$ & \\
\hline $\begin{array}{l}2 \\
\dot{H} \\
\dot{B}\end{array}$ & $\underset{\Xi}{\infty}$ & 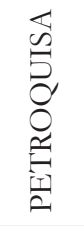 & 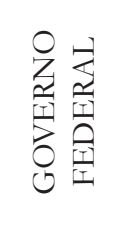 & 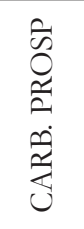 & ${ }_{n}^{\infty}$ & 吾 & \\
\hline $\begin{array}{c}0 \\
0 \\
0 \\
0 \\
0 \\
0\end{array}$ & 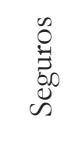 & 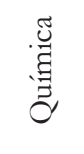 & 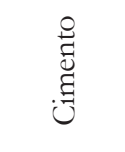 & 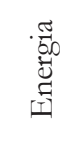 & 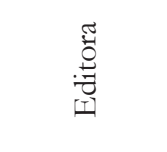 & 䒴 & \\
\hline 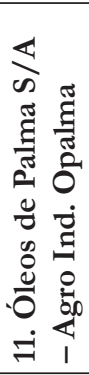 & 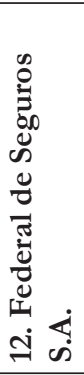 & 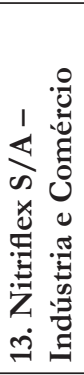 & 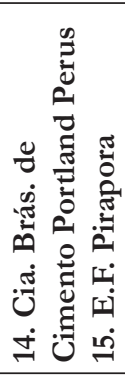 & 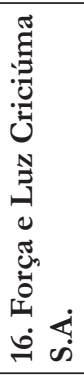 & 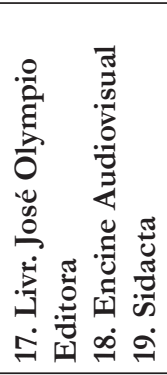 & 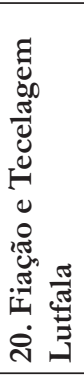 & 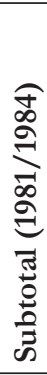 \\
\hline
\end{tabular}

Anos 90, Porto Alegre, v. 21, n. 39, p. 363-397, jul. 2014 
As vinte empresas privatizadas encontravam-se nos setores de papel e celulose (Rio Grande Cia. de Celulose do Sul, Florestal Rio Cell, Indústria Brasileira de Papel - Indrapel), têxtil (Cia. América Fabril, Fábrica de Tecidos Dona Isabel, Fiação e Tecelagem Lutfala), siderurgia (Nitriflex S/A - Indústria e Comércio, Cia. Bras. de Cimento Portland Perus), energético (Força e Luz Criciúma S.A) e audiovisual (Encine Audiovisual). Constam também uma editora (José Olympio) e uma empresa de sistemas educacionais (Sindacta).

Os controladores das empresas privatizadas, além do Governo Federal, eram o Banco Central, o BNDES, a BNDESPAR (subsidiária do BNDES), a Petroquisa e a CSN. Em sua grande maioria, eram empresas de médio porte, sendo que apenas quatro delas possuíam mais de quinhentos empregados (Coperbo, Óleos Palma, Federal de Seguros e a Cia. Bras. de Cimento Portland).

\section{Gráfico 1 - Valor de venda de cada empresa no total das privatizações realizadas entre 1981 e 1984 (Em \%)}
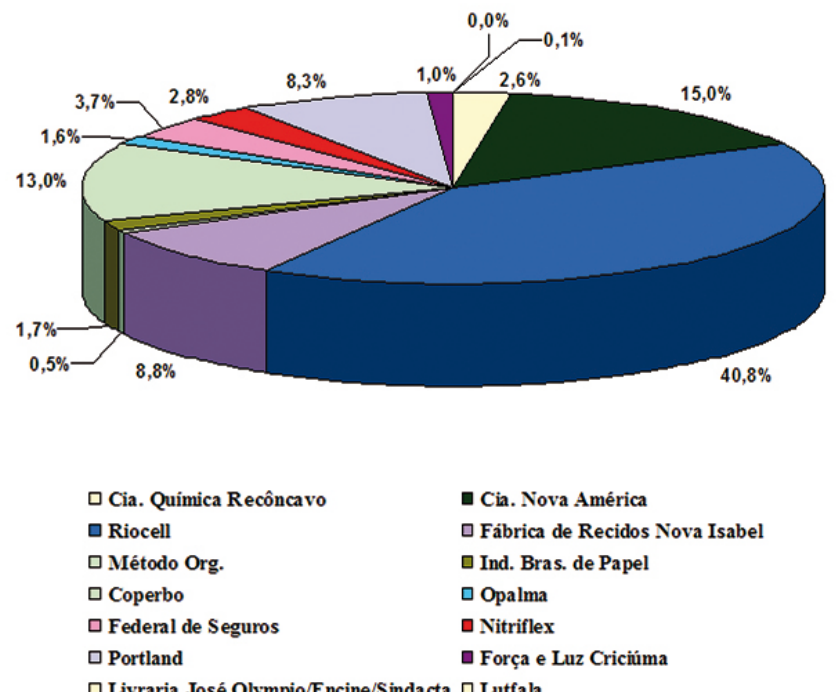

$\square$ Livraria José Olympio/Encine/Sindacta $\square$ Lutfala

Fonte: Conselho Federal de Desestatização. Relatório (1981-84) Anexo A e B. Elaboração Própria. 
Dos processos de venda das empresas estatais no período 1981-1984, a transação de maior vulto foi realizada com a privatização das empresas Riocell, Rio Grande Cia. de Celulose do Sul e da Florestal Rio Cell, compradas, conjuntamente, pela KJV participações, sociedade constituída pelos grupos Klabin, Lochepe e Votorantin. Dos US\$ 190.038,50 arrecadados com a venda de todas as empresas, $40 \%$ foram oriundos dessa única transação, o que demonstra a força econômica da sociedade constituída pela Klabin, Lochepe e Votorantim.

Os valores de venda das demais empresas ficaram muito abaixo daquele da Riocell. Os dois mais elevados foram obtidos na Cia. Nova América Fabril (14\%) e na Coperbo (13\%), ambas adquiridas por outras empresas.

Além da importância que os grupos Klabin, Lochepe e Votorantim tiveram nas privatizações desse período, outra participação merece ser destacada: a compra da Indústria Brasileira de Papel, pelo Banco Bamerindus. Embora o valor de venda tenha sido um dos mais baixos (apenas $2 \%$ do montante das vendas para uma empresa de 401 empregados), sobressai-se a inserção direta do capital bancário nas privatizações em um processo ainda marcado pela incorporação das empresas vendidas em sua maioria para instituições do mesmo ramo.

A grande especificidade deste projeto de privatização em

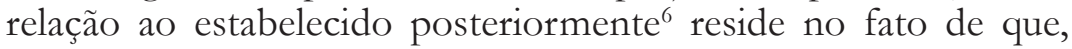
durante o Governo Figueiredo, a política de privatização não deveria alcançar nem enfraquecer as empresas públicas cujo controle o Governo considerasse intransferível. Ainda inserido na Doutrina de Segurança Nacional, deveriam ser excluídas do processo de privatização as empresas que fossem fundamentais para a viabilização não só do fortalecimento do setor privado como também para o controle nacional do processo de desenvolvimento. Assim sendo, não estavam incluídas nos dispositivos do decreto $n^{\circ}$. 86.215 as empresas incumbidas de atividades diretamente ligadas à segurança nacional - cujo critério seria definido pelo próprio Presidente da República -, e aquelas sujeitas ao regime legal de monopólio estatal. Ou seja, 
[...] as empresas responsáveis pela operação da infraestrutura econômica ou social básica ou produtoras de insumos de importância estratégica, cujo controle o Estado foi levado a assumir para viabilizar o desenvolvimento do setor privado, e não para com ele competir (art. $4^{\circ}$. \ III).

Excluídas também encontravam-se "[...] as empresas instituídas com o objetivo de manter o controle nacional do processo de desenvolvimento ou evitar a desnacionalização de setores básicos da economia" (art. $4^{\circ}$. S IV).

Constitui-se em preocupação, também, o estabelecimento de critérios básicos que deveriam nortear o processo de privatização. Em primeiro lugar, uma ampla divulgação da operação de transferência como forma de assegurar o conhecimento público das condições em que se processaria a transferência, bem como a situação econômica, financeira e operacional da empresa a ser privatizada (art. $5^{\circ}$. $\int \mathrm{I}$ ).

A defesa do nacionalismo fica explícita quando da restrição dos adquirentes das empresas que seriam privatizadas a brasileiros ou a empresas ou grupos empresariais sob controle nacional (art. $5^{\circ}$. \II). Além disso, seria estabelecido, mediante compromisso irrevogável, que os adquirentes obrigar-se-iam a "[...] manter sob controle nacional o capital e a administração das empresas adquiridas" (art. 5\%. \ III).

Em relação às Empresas Estatais, deveriam ser desativadas aquelas cuja manutenção sob controle estatal fosse considerado inviável do ponto de vista legal, econômico e administrativo, que, principalmente, não despertassem o interesse do setor privado em sua aquisição (art. $7^{\circ}$.). Aquelas que desempenhassem funções concorrenciais com o setor privado e que também não despertassem interesse, não poderiam mais expandir suas atividades e seus investimentos seriam limitados às necessidades básicas de sua viabilização econômica (art. $8^{\circ}$ ).

Pelo que foi apresentado até aqui acerca da legislação que regulamentou os primeiros passos do programa de privatização no Brasil, havia importantes obstáculos que impediram o efetivo avanço da privatização das Empresas Estatais ainda durante a gestão do General Figueiredo. 
Os decretos supramencionados ainda refletiam, pesadamente, uma concepção de atuação estatal marcada pela Doutrina de Segurança Nacional e pela defesa do nacionalismo. No período entre 1974 e 1982, várias empresas que passavam por dificuldades financeiras, ou não foram capazes de pagar os financiamentos que obtiveram, e/ou honrar avais e fianças concedidos, passaram ao controle do Sistema BNDES.

\section{Quadro 2 - Empresas absorvidas pelo Sistema BNDES (1974-1982)}

\begin{tabular}{|c|c|c|c|c|}
\hline Empresas & $\begin{array}{c}\text { Setor de } \\
\text { Atividade }\end{array}$ & $\begin{array}{c}\text { Porte } \\
\text { Econômico }\end{array}$ & UF & $\begin{array}{c}\text { Ano da } \\
\text { Estatização }\end{array}$ \\
\hline $\begin{array}{l}\text { Caraíba Metais } \\
\text { S.A. }\end{array}$ & $\begin{array}{l}\text { Mineração e } \\
\text { Metalurgia do } \\
\text { Cobre }\end{array}$ & Grande Empresa & $\mathrm{BA}$ & 1974 \\
\hline $\begin{array}{l}\text { Celpag - Cia. } \\
\text { Guatapará de Papel } \\
\text { e Celulose }\end{array}$ & Papel e Celulose & Grande Empresa & SP & 1981 \\
\hline $\begin{array}{l}\text { CCB - Cia. de } \\
\text { Celulose da Bahia }\end{array}$ & Papel e Celulose & Grande Empresa & $\mathrm{BA}$ & 1978 \\
\hline $\begin{array}{l}\text { CBC - Cia. } \\
\text { Brasileira do Cobre }\end{array}$ & Mineração & Média Empresa & $\mathrm{RS}$ & 1974 \\
\hline $\begin{array}{l}\text { Cia. Nacional } \\
\text { de Tecido Nova } \\
\text { América }\end{array}$ & Têxtil & Grande Empresa & $\mathrm{RJ}$ & 1985 \\
\hline $\begin{array}{l}\text { Cosinor - Cia. } \\
\text { Siderúrgica do } \\
\text { Nordeste }\end{array}$ & Siderurgia & Grande Empresa & PE & 1982 \\
\hline Mafersa S.A. & Bens de Capital & Grande Empresa & $\mathrm{SP}$ & 1984 \\
\hline $\begin{array}{l}\text { Máquinas } \\
\text { Piratininga S.A. }\end{array}$ & Bens de Capital & $\begin{array}{l}\text { Pequena } \\
\text { Empresa }\end{array}$ & $\mathrm{SP}$ & 1982 \\
\hline $\begin{array}{l}\text { Máquinas } \\
\text { Piratininga do } \\
\text { Nordeste S.A }\end{array}$ & Bens de Capital & $\begin{array}{l}\text { Pequena } \\
\text { Empresa }\end{array}$ & PE & 1982 \\
\hline $\begin{array}{l}\text { Sibra - } \\
\text { Eletrosiderúrgica } \\
\text { Brasileira S.A }\end{array}$ & Ferro-Ligas & Grande Empresa & $\mathrm{BA}$ & 1982 \\
\hline
\end{tabular}

Fonte: BNDES: Privatização - A Experiência da BNDESPAR (1987-1989), 1992. 
Das empresas absorvidas pelo sistema BNDES no período entre 1974 e 1982, duas eram no ramo de papel e celulose (CELPAG e CCB), duas mineradoras (Caraíba Metais e $\mathrm{CBC}$ ), uma do setor têxtil (Nova América), uma siderúrgica (Cosinor), três de bens de capital (Mafersa, Máquinas Piratininga e Máquina Piratininga do Nordeste) e uma de ferro-ligas (SIBRA). A maioria delas constituía-se em grandes empresas e se concentravam em apenas cinco estados (três na Bahia, três em São Paulo, duas em Pernambuco, uma no Rio Grande do Sul e uma no Rio de Janeiro).

Tais empresas foram posteriormente incluídas no programa de privatização. Durante o Governo Sarney, foram privatizadas a CELPAG, a CCB, a CBBC, a Nova América, a Máquinas Piratininga e a SIBRA. Durante o Governo Collor, a COSINOR e a MAFERSA. Por fim, durante o governo de Fernando Henrique, deu-se a privatização da Caraíba Metais.

O sistema BNDES acumulou, ainda, expressiva participação em algumas empresas, através de ações ou de créditos detidos, o que implicou, a maioria das vezes, responsabilidades ajustadas por acordo de acionistas. Caracterizava-se, assim, como uma participação de controle compartilhado. Essas empresas encontram-se descriminadas no quadro a seguir.

\section{Quadro 3 - Empresas não controladas com grande envolvimento com o Sistema BNDES}

\begin{tabular}{|l|c|c|c|c|}
\hline Empresas & $\begin{array}{c}\text { Setor de } \\
\text { Atividade }\end{array}$ & $\begin{array}{c}\text { Porte } \\
\text { Econômico }\end{array}$ & UF & $\begin{array}{c}\text { Participação } \\
\text { Acionária }\end{array}$ \\
\hline $\begin{array}{l}\text { Aracruz } \\
\text { Celulose S.A. }\end{array}$ & $\begin{array}{c}\text { Papel e } \\
\text { Celulose }\end{array}$ & $\begin{array}{c}\text { Grande } \\
\text { Empresa }\end{array}$ & ES & $\begin{array}{c}\text { Controle compar- } \\
\text { tilhado entre a } \\
\text { BNDESPAR e outros } \\
\text { grupos, regulado } \\
\text { através de Acordo de } \\
\text { Acionistas }\end{array}$ \\
\hline $\begin{array}{l}\text { Cimetal } \\
\text { Siderurgia S.A. }\end{array}$ & Siderurgia & $\begin{array}{c}\text { Grande } \\
\text { Empresa }\end{array}$ & MG & $\begin{array}{c}\text { Controle comparti- } \\
\text { lhado entre o BNDES } \\
\text { e o BDMG }\end{array}$ \\
\hline
\end{tabular}




\begin{tabular}{|c|c|c|c|c|}
\hline $\begin{array}{l}\text { Cobra } \\
\text { Computadores } \\
\text { e Sistemas } \\
\text { Brasileiros S.A. }\end{array}$ & Informática & $\begin{array}{l}\text { Grande } \\
\text { Empresa }\end{array}$ & RJ & $\begin{array}{c}\text { Controle comparti- } \\
\text { lhado entre o BNDES, } \\
\text { a CEF e o Banco do } \\
\text { Brasil }\end{array}$ \\
\hline $\begin{array}{l}\text { CRN - Cia. } \\
\text { Riograndense } \\
\text { de } \\
\text { Nitrogenados }\end{array}$ & Energético & $\begin{array}{c}\text { Média } \\
\text { Empresa }\end{array}$ & RS & $\begin{array}{c}\text { Controle compar- } \\
\text { tilhado entre } \\
\text { BNDESPAR, } \\
\text { Petrofértil e o Estado } \\
\text { do Rio Grande do Sul. }\end{array}$ \\
\hline $\begin{array}{l}\text { Siderúrgica } \\
\text { N.S. Aparecida } \\
\text { S.A. }\end{array}$ & Siderurgia & $\begin{array}{c}\text { Média } \\
\text { Empresa }\end{array}$ & SP & $\begin{array}{c}\text { Embora não deti- } \\
\text { vesse o controle da } \\
\text { Companhia, o Sistema } \\
\text { BNDES possuía } \\
\text { responsabilidades que } \\
\text { o identificavam quase } \\
\text { como acionista contro- } \\
\text { lador (detentor de } 55 \% \\
\text { do capital total, } 38,4 \% \\
\text { do capital votante e } \\
80 \% \\
\text { do endividamento } \\
\text { da empresa) }\end{array}$ \\
\hline $\begin{array}{l}\text { Usiminas } \\
\text { Mecânica S.A } \\
\text { - Usimec }\end{array}$ & $\begin{array}{l}\text { Bens de } \\
\text { Capital }\end{array}$ & $\begin{array}{c}\text { Média } \\
\text { Empresa }\end{array}$ & MG & $\begin{array}{l}\text { Controle assumido } \\
\text { pelo BNDES por } \\
\text { ocasião da cisão } \\
\text { da Usiminas }\end{array}$ \\
\hline
\end{tabular}

Fonte: BNDES: Privatização - A Experiência da BNDESPAR (1987-1989), 1992

A participação do sistema BNDES em empresas que não estavam totalmente sob seu controle já aponta para uma característica importante da ação estatal dos anos noventa: a parceria público-privado. Das seis empresas em que houve a sua participação, em uma delas o BNDES compartilhou o controle acionário com o capital privado: na Cimental Siderurgia, com o Banco de Desenvolvimento de Minas Gerais (BDMG). Nesse período, todavia, ainda predominava o capital do setor produtivo estatal. Assim, a participação acionária foi compartilhada com a Caixa Econômica Federal, o Banco do Brasil, outras Empresas Estatais e governos estaduais. 
A partir de 1982, a BNDESPAR acabou por se envolver na administração das empresas que se tornaram suas controladas, seja diretamente através de suas próprias operações com essas empresas, seja através daquelas absorvidas pelo BNDES, as quais foram posteriormente transferidas ao controle de sua subsidiária (BNDES, 1992). Já pós-1987, a BNDESPAR, BNDES Participações S.A., subsidiária do $\mathrm{BNDES}^{7}$, voltou sua atenção no sentido de devolver à iniciativa privada as empresas que se encontravam sob controle acionário do Sistema BNDES. Assim sendo, a Aracruz Celulose, a Cimental, e a Siderúrgica Nossa Senhora da Aparecida foram privatizadas durante o governo Sarney. A USIMINAS, durante o governo Collor.

O terceiro marco jurídico do processo de privatização no Brasil data do Governo Sarney. O decreto n ${ }^{\text {o. }}$ 91.991, de 28 de novembro de 1985, dispôs sobre o processo de privatização de empresas sob controle direto ou indireto do Governo Federal e estipulou que "[...] compreenderá indistintamente a abertura do capital social, alienação de participações acionárias e desativação dessas empresas" (art. $1^{\circ}$.).

Apesar da pouca efetividade prática das iniciativas legais do Governo Figueiredo, nas duas mais importantes determinações do decreto de 1985, foram mantidas integralmente as disposições dos decretos anteriores. Assim sendo, estariam aptas a inserirem-se no programa de privatização as empresas que foram criadas pelo setor privado e que, em decorrência de obrigações ou execução de garantias, passaram para o controle direto ou indireto do Governo Federal (art. $3^{\circ}$. \I) e cujas atividades pudessem ser exercidas pelo setor privado (art. $3^{\circ}$. \II). Enquadravam-se também aquelas empresas cujas subsidiárias não fossem indispensáveis à execução dos objetivos essenciais da empresa controladora e importassem em injusta ou desnecessária competição com as empresas privadas (art. $3^{\circ}$. S III).

Destarte, apesar da dimensão restrita do projeto privatista do Governo Figueiredo, os dispositivos legais então instituídos e, principalmente, as (des)orientações da política econômica, constituíram-se em passos importantes para o fortalecimento do projeto privatista a ser implementado pelos governos posteriores. 


\section{A Estatização da Dívida Externa e a Crise nas Empresas Estatais}

Os principais defensores da agenda neoliberal argumentavam que a irracionalidade administrativa das Empresas Estatais brasileiras, a corrupção endêmica, aliada à sangria que seu custeio gerava nos cofres públicos, justificariam o projeto de privatização. No entanto, a hipótese que aqui está sendo defendida é que o quadro de profunda crise apresentado por tais empresas nos anos noventa tem suas origens nas estratégias governamentais implementadas desde meados da década de sessenta, principalmente a partir de 1974.

Como eixos da estratégia apresentada no II Plano Nacional de Desenvolvimento (PND), em 1974, encontravam-se o desenvolvimento dos setores de base (bens de capital, indústria eletrônica de base e da área de insumos básicos, tais como siderúrgicos, fertilizantes, papel, celulose, cimento, enxofre), a abertura de novos campos para a exportação de manufaturados, o impulso ao desenvolvimento da indústria de alimentos e a atenuação dos desníveis regionais de desenvolvimento industrial. No centro de tais metas, encontravam-se as Empresas Estatais, consideradas os agentes fortalecedores do capital nacional e da indústria de bens de capital. Deveriam atuar principalmente em áreas onde o capital privado não se envolveria em função tanto da magnitude dos recursos exigidos quanto ao longo tempo necessário para retorno do investimento (CAMPOS, 1990, p. 49).

Segundo Biasoto Jr. (1987), podem ser identificadas três vertentes no processo de estatização da dívida externa brasileira: a crescente participação das entidades públicas na captação de recursos externos, a transferência da dívida externa (originalmente captada pelo setor privado) às autoridades monetárias e a forma de negociação da dívida externa que transformou, a partir de 1983, o Banco Central em depositário de expressiva parcela de recursos externos.

O progressivo processo de estatização da dívida externa brasileira pode ser claramente visualizado nas tabelas a seguir. 
A Reestruturação do Setor Público Estatal Brasileiro...
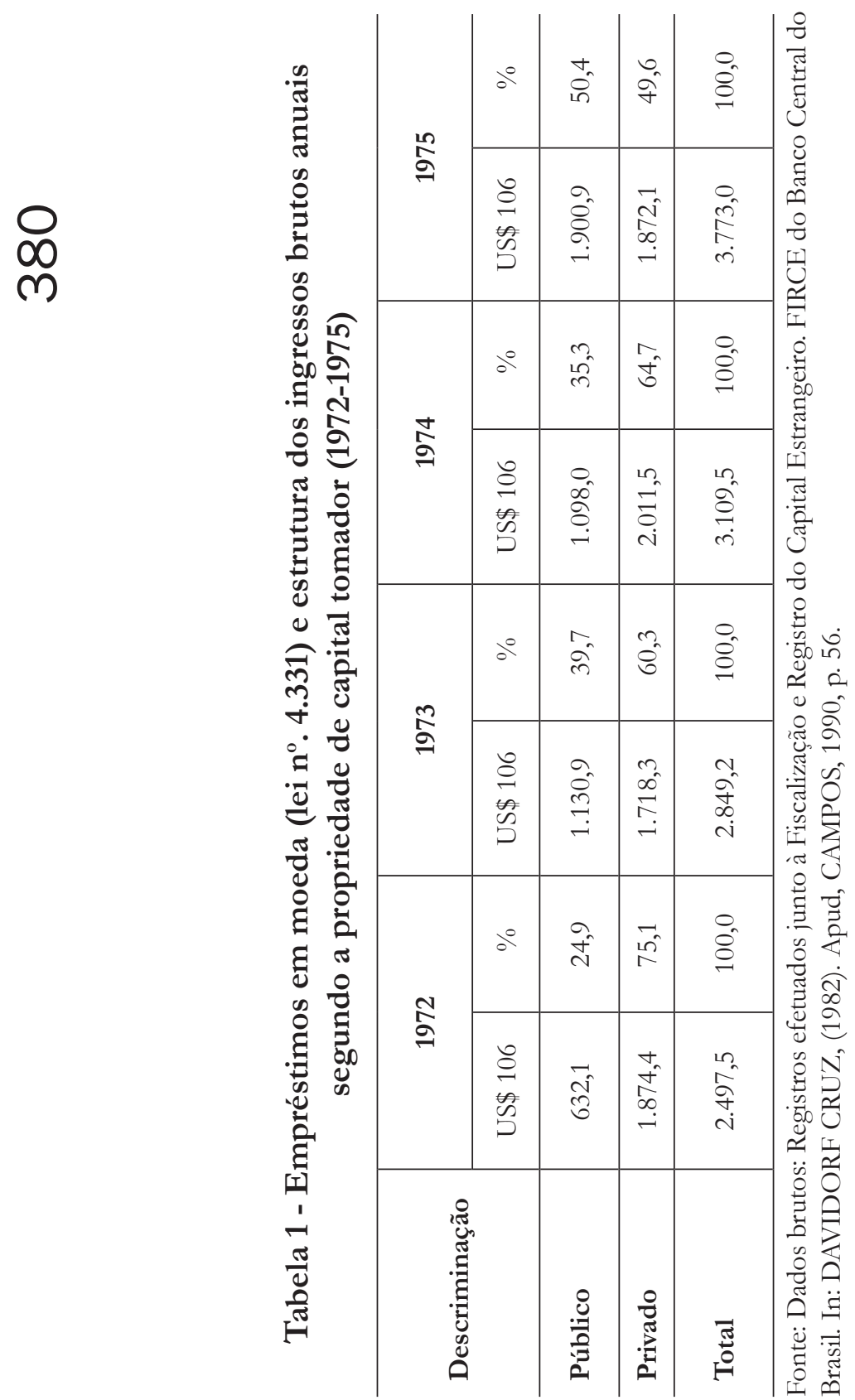

Anos 90, Porto Alegre, v. 21, n. 39, p. 363-397, jul. 2014 
Gráfico 2 - Empréstimos em moeda (lei no. 4.331) e estrutura dos ingressos brutos anuais segundo a propriedade de capital tomador (1972-1975)

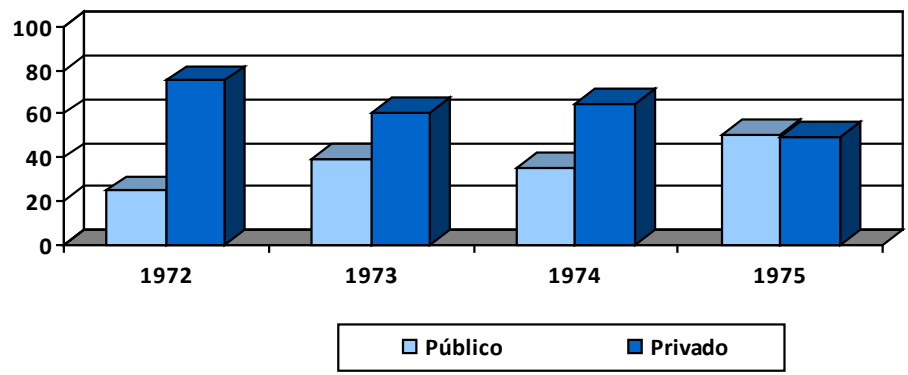

Fonte: Dados brutos: Registros efetuados junto à Fiscalização e Registro do Capital Estrangeiro. FIRCE do Banco Central do Brasil. In: DAVIDORF CRUZ (1982). Apud, CAMPOS, 1990, p. 56. Elaboração Própria. 
A Reestruturação do Setor Público Estatal Brasileiro...

$m$

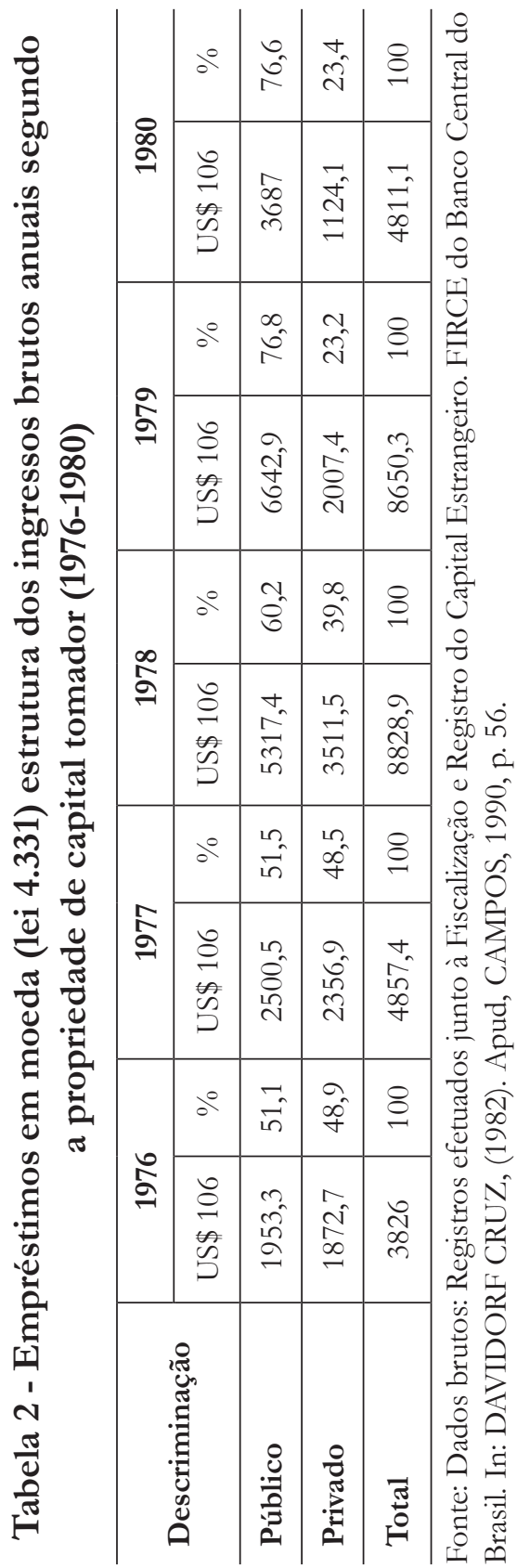

Anos 90, Porto Alegre, v. 21, n. 39, p. 363-397, jul. 2014 


\section{Gráfico 3 - Empréstimos em moeda (lei 4.331) estrutura dos ingressos brutos anuais segundo a propriedade de capital tomador (1976-1980)}

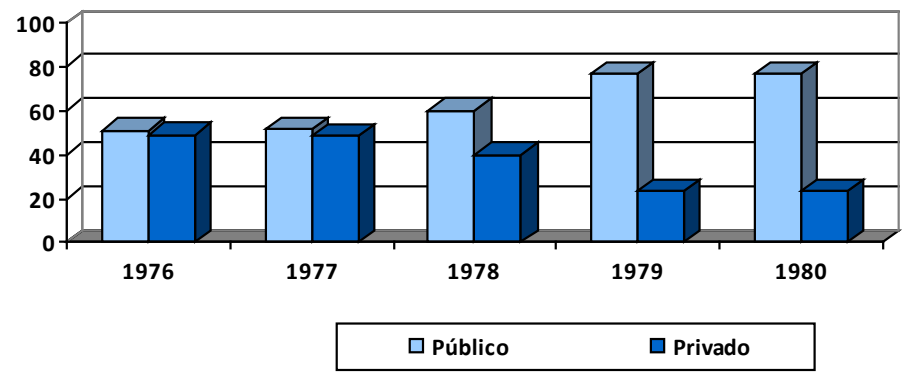

Fonte: Dados brutos: Registros efetuados junto à Fiscalização e Registro do Capital Estrangeiro. FIRCE do Banco Central do Brasil. In: DAVIDORF CRUZ (1982), Apud, CAMPOS, 1990, p. 56. Elaboração Própria.

A trajetória do processo de estatização da dívida externa brasileira - que em muito contribuiu para a crise das Empresas Estatais nos anos 1980 -, pode ser claramente visualizado através dos dados apresentados nas tabelas 1 e 2 e nos gráficos 2 e 3 . O setor privado, que em 1972 era responsável por 75,1\% dos ingressos de capital estrangeiro no país, chega ao ano de 1980 sendo responsável por apenas 23,4\%. Durante esse período, foi somente entre os anos de 1973 e 1974 que ocorreu um ligeiro crescimento desse percentual. No auge do "milagre econômico", o setor privado ainda era responsável por $64,7 \%$ dos recursos captados no exterior. Em todos os demais anos abarcados pelos gráficos e tabelas (de 1972 a 1980), a participação do setor privado só foi sendo reduzida. Seguindo a trajetória diametralmente oposta, a participação do setor público cresceu a cada ano. Se em 1972 era responsável por apenas 24,9\% do total dos empréstimos em moeda que ingressaram no país, o setor público chegou ao ano de 1980 contabilizando 76,6\%.

Nesse processo de estatização da dívida externa, Adriana Fiorotti Cardoso (1990) identifica dois momentos distintos. Uma etapa inicial, entre 1973 e 1979, marcada pelo crescente peso do setor público, principalmente das estatais, nas contratações anuais 
de novos empréstimos externos. Nesse momento, houve a implementação de dois mecanismos governamentais que em muito foram os responsáveis pela crise das Empresas Estatais na década de 1980. Em primeiro lugar, os preços e tarifas públicas foram utilizados como instrumentos de combate à inflação. Além disso, atuaram também como mecanismo de concessão de subsídios ao setor privado, via mudança dos preços relativos. Esses mecanismos inviabilizaram o autofinanciamento das Estatais. Nesse processo, houve um reforço financeiro do BNDE, sob a forma de crédito subsidiado, para os capitais privados.

Em uma segunda etapa, entre 1979 e meados da década seguinte, a estatização da dívida e o favorecimento do setor privado foram ainda mais além. No centro desse processo encontrava-se o Banco Central com suas novas atribuições: defesa contra o risco cambial; principal tomador de empréstimos junto aos bancos internacionais à disposição do setor privado $\left(\mathrm{DRME}^{8}\right)$ e receptador das dívidas ainda a vencer contratadas originalmente pelo setor privado.

$\mathrm{Na}$ análise do processo de estatização da dívida externa brasileira e do papel que nela assumiram as Empresas Estatais, Rogério Furquim Werneck (1986) defende que o ônus do ajuste interno recaiu sobre o setor público. Mais ainda, a crise das Empresas Estatais, vista por muitos como fruto da resistência do setor público em se adequar às novas condições da economia brasileira, acabou por sustentar as propostas de corte de investimento e de gastos correntes em todos os níveis do setor público, inclusive nas Empresas Estatais.

\section{Tabela 3 - Distribuição do PIB - 1970-1983 (valores em percentagem do PIB)}

\begin{tabular}{c|c|c|c|c}
\hline Anos & $\begin{array}{c}\text { Renda Líquida } \\
\text { enviada ao } \\
\text { exterior }\end{array}$ & $\begin{array}{c}\text { Renda } \\
\text { disponível do } \\
\text { setor público }\end{array}$ & $\begin{array}{c}\text { Renda } \\
\text { disponível do } \\
\text { setor privado }\end{array}$ & PIB \\
\hline $\mathbf{1 9 7 0}$ & 0,94 & 16,63 & 82,43 & 100,00 \\
\hline $\mathbf{1 9 7 1}$ & 0,94 & 16,81 & 82,25 & 100,00 \\
\hline $\mathbf{1 9 7 2}$ & 0,96 & 16,64 & 82,40 & 100,00 \\
\hline $\mathbf{1 9 7 3}$ & 0,92 & 16,84 & 82,24 & 100,00 \\
\hline $\mathbf{1 9 7 4}$ & 0,87 & 14,34 & 84,78 & 100,00 \\
\hline
\end{tabular}




\begin{tabular}{c|c|c|c|c}
\hline $\mathbf{1 9 7 5}$ & 1,39 & 14,43 & 84,18 & 100,00 \\
\hline $\mathbf{1 9 7 6}$ & 1,53 & 14,85 & 83,62 & 100,00 \\
\hline $\mathbf{1 9 7 7}$ & 1,62 & 13,38 & 85,01 & 100,00 \\
\hline $\mathbf{1 9 7 8}$ & 2,23 & 11,59 & 86,18 & 100,00 \\
\hline $\mathbf{1 9 7 9}$ & 2,58 & 11,57 & 85,85 & 100,00 \\
\hline $\mathbf{1 9 8 0}$ & 3,07 & 10,05 & 86,88 & 100,00 \\
\hline $\mathbf{1 9 8 1}$ & 3,96 & 9,97 & 86,07 & 100,00 \\
\hline $\mathbf{1 9 8 2}$ & 5,10 & 10,29 & 84,61 & 100,00 \\
\hline $\mathbf{1 9 8 3}$ & 5,69 & 8,67 & 85,64 & 100,00 \\
\hline
\end{tabular}

Fonte: Contas Nacionais. Apud, Werneck, 1986, p. 557.

\section{Gráfico 4 - Distribuição do PIB - 1970-1983 (valores em percentagem do PIB)}

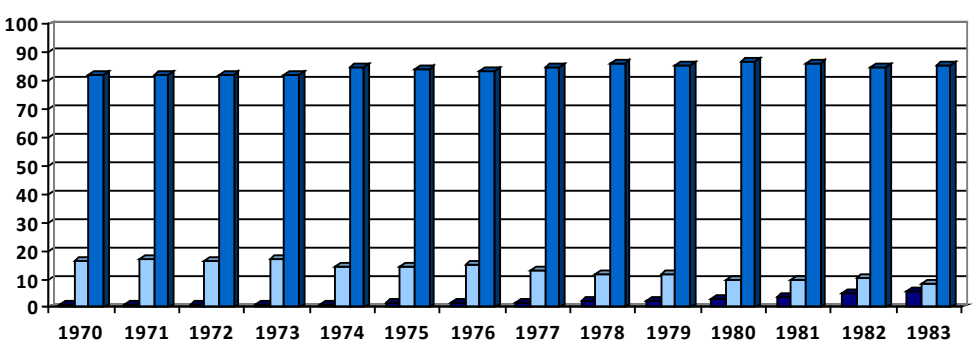

— Renda líquida enviada ao exterior $\square$ Renda Disponível do setor público $\square$ Renda disponível do setor privado

Fonte: Contas Nacionais. Apud, Werneck, 1986, p. 557. Elaboração Própria.

Pelos dados da tabela 3 e do gráfico 4, pode ser percebido que o ônus do ajuste de fato recaiu sobre o setor público. No período 1970-1973, a tendência decrescente da renda disponível deste último não foi contínua. Alternaram-se momentos de aumento e de recuo. Entre os anos 1970 e 1971, o percentual alterou-se positivamente, o que significou a redução da renda disponível do setor privado na mesma proporção. Essa tendência inverteu-se em 1972, embora de forma leve, ficando a renda disponível ao Setor Público reduzida em 0,20\%. No ano de 1974, todavia, deu-se a maior variação negativa desde 1970 . Ocorreu a redução de mais de $2,5 \%$ e o percentual passou de 16,84 para $14,34 \%$. Nos dois anos 
seguintes, houve uma pequena alteração positiva desse valor que, entretanto, a partir de 1977, sofreu nova queda brusca. A partir de então, a curva decrescente da renda disponível do setor público só acentuou-se.

Os dados demonstram, dessa forma, o quanto coube ao setor público arcar com os custos do ajuste econômico. Embora tenha havido um crescimento significativo do percentual do PIB enviado ao exterior (que entre 1970 e 1983 passou de 0,94\% para 5,69\%), a renda disponível do setor privado não foi negativamente alterada. Pelo contrário. Oscilou sempre na casa dos $80 \%$, chegando ao patamar de 85,64\% em 1983. A renda disponível do setor público seguiu o caminho diametralmente oposto. Entre 1970 e 1983, foi reduzida à metade. Se em 1970 era de 16,63\%, chegou a 1983 com o valor de apenas $8,67 \%$.

A política econômica implementada a partir dos anos setenta, assim, privilegiou o financiamento dos investimentos estatais através de recursos externos, independentemente da real necessidade de divisas envolvida nesses investimentos. A viabilização do balanço de pagamentos deu-se a partir do financiamento dos investimentos do setor público através da captação de recursos externos. Na origem da crise das Empresas Estatais da década de 1980, entretanto, ainda podem ser incluídos o cerceamento do acesso de tais empresas a fontes internas de financiamento e a política de reajuste de preços e tarifas como mecanismo de controle da inflação.

Nesse processo de utilização das Empresas Estatais como elementos captadores de recursos externos, cuja credibilidade era um elemento favorável no momento de contratação dos empréstimos estrangeiros, ocorreu o financiamento do déficit em transações correntes da economia como um todo. Até pelo menos 1980, tal estratégia permitira a expansão do nível de atividades em todos os setores.

O fato de os empréstimos terem sido contraídos primordialmente pelo setor público adveio, inicialmente, da mera decisão de explorar as constatadas vantagens comparativas deste setor na captação e, posteriormente, da decisão de socializar o risco cambial envolvido nos novos empréstimos (WERNECK, 1986, p. 554). 
Nesse exercício de demonstração dos efeitos que a orientação da política econômica brasileira teve sobre o Setor Produtivo Estatal, outra variável será agora objeto de análise: os gastos com salários e encargos, bem como as despesas financeiras das empresas não financeiras com participação do governo federal entre 1970 e 1982.

Uma das maiores críticas às Empresas Estatais que nos anos noventa sustentaram e justificaram para muitos o processo de privatização, era seu elevado grau de despesas com salários do funcionalismo público. Os dados da tabela 4 demonstram não só a fragilidade desse argumento como também e, principalmente, clarificam o real significado da ideia aqui defendida de que recaiu sobre o Setor Produtivo Estatal o ônus do ajuste financeiro.

\section{Tabela 4 - Dados agregados de empresas não financeiras com participação do governo federal: 1970-1982 (valores em percentagem do PIB)}

\begin{tabular}{c|c|c}
\hline Anos & Salários e Encargos & Despesas Financeiras \\
\hline $\mathbf{1 9 7 0}$ & 1,82 & 0,27 \\
\hline $\mathbf{1 9 7 1}$ & 1,82 & 0,28 \\
\hline $\mathbf{1 9 7 2}$ & 1,82 & 0,35 \\
\hline $\mathbf{1 9 7 3}$ & 2,24 & 0,43 \\
\hline $\mathbf{1 9 7 4}$ & 1,89 & 0,56 \\
\hline $\mathbf{1 9 7 5}$ & 1,97 & 1,05 \\
\hline $\mathbf{1 9 7 6}$ & 1,84 & 1,37 \\
\hline $\mathbf{1 9 7 7}$ & 1,95 & 1,30 \\
\hline $\mathbf{1 9 7 8}$ & 1,94 & 1,90 \\
\hline $\mathbf{1 9 7 9}$ & 2,42 & 2,88 \\
\hline $\mathbf{1 9 8 0}$ & 2,40 & 2,78 \\
\hline $\mathbf{1 9 8 1}$ & 2,51 & 3,57 \\
\hline $\mathbf{1 9 8 2}$ & 2,66 & 4,28 \\
\hline
\end{tabular}

Fonte: Estimada a partir de dados publicados em Costa (1985). Apud, WERNECK, 1986, p. 570 


\section{Gráfico 5 - Dados agregados de empresas não financeiras} com participação do governo federal: 1970-1982 (valores em percentagem do PIB)

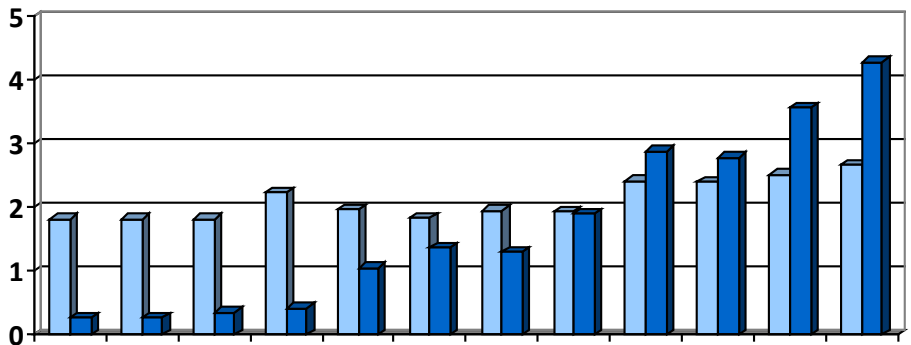

197019711972197319751976197719781979198019811982

\section{Salários e Encargos $\square$ Despesas Financeiras}

Fonte: Dados estimados a partir de dados publicados em Costa (1985). Apud, WERNECK, 1986, p. 570. Elaboração Própria.

Se houve uma ligeira alteração no percentual gasto pelas Empresas Estatais com salários e encargos no período entre 1970 e 1982, passando de 1,82\% do PIB em 1970 para 2,66\% em 1982, o mesmo não pode ser dito em relação aos gastos com as despesas financeiras.

Uma vez que a política de captação de recursos estrangeiros explorou a credibilidade do Setor Produtivo Estatal e de seus projetos de investimento junto ao sistema bancário (WERNECK, 1986), o gasto com as despesas financeiras em pouco mais de uma década teve um crescimento exponencial. Se em 1970 tais gastos representavam apenas $0,27 \%$ do PIB, a partir de 1975 , passaram a absorver percentuais cada vez mais significativos. Na comparação entre as duas variáveis aqui analisadas, é possível perceber as disparidades entre o crescimento dos gastos com salários e encargos e aqueles com as despesas financeiras. O ano de 1975 é revelador nesse sentido. Se com os primeiros houve um crescimento de apenas $0,8 \%$, no que se refere às despesas financeiras, o percentual quase que duplicou. Não é mera coincidência que tais números tenham ocorrido exatamente no momento de implementação da política econômica do II Plano Nacional de Desenvolvimento. 
Esses números são decorrentes do novo papel que as Empresas Estatais passaram a assumir nas estratégias macroeconômicas do Governo Geisel.

O ano de 1976 é ainda mais revelador desse quadro. O percentual dos gastos com salários e encargos reduz-se $0,13 \%$ enquanto os gastos com as despesas financeiras aumentam $0,32 \%$. O abandono da estratégia do II PND de "crescimento a qualquer custo", como já indicado anteriormente, é questionada no ano de 1977. Isso refletiu-se no ligeiro aumento dos gastos com salários e encargos, $0,11 \%$, e na redução das despesas financeiras. No entanto, já no ano seguinte, a despeito da mínima redução dos gastos com salários e encargos, apenas 0,01\%, as despesas financeiras voltam a subir de forma significativa, 0,60\%. A partir de então, a única exceção a essa crescente espiral das despesas financeiras foi o ano de 1980, período imediatamente posterior ao segundo choque do petróleo e ao primeiro ano de mandato do último General Presidente.

Assim sendo, nos anos 1981 e 1982, os níveis retornam ao patamar anterior. Consolidou-se, dessa forma, uma significativa desproporção entre o crescimento dos gastos das Empresas Estatais não financeiras, em torno de $0,10 \%$, e os gastos com as despesas financeiras, em torno de $0,70 \%$.

Dessa forma, a crise que as Empresas Estatais não financeiras apresentam no início dos anos oitenta pode ser explicada, fundamentalmente, pelos desdobramentos da política econômica dos governos brasileiros a partir da década de setenta. A redução da renda disponível do setor público, ao lado do aumento das despesas financeiras, lançaram as Empresas Estatais na profunda crise que explodiu nos anos oitenta.

Diante de tal cenário, agravado pelo cerceamento do acesso das Empresas Estatais às fontes de financiamento internas, pela política de reajuste de preços e tarifas abaixo da inflação, desenhou-se o quadro presente na tabela 5 e no gráfico 6 . 
A Reestruturação do Setor Público Estatal Brasileiro...

Tabela 5 - Consumo e poupança em conta corrente do governo - 1970/1983 (valores em percentagem do PIB)

\begin{tabular}{|c|c|c|c|c|c|}
\hline \multirow[b]{2}{*}{ Anos } & \multirow{2}{*}{$\begin{array}{c}\text { Renda } \\
\text { disponível } \\
\text { do setor } \\
\text { público } \\
\text { (A) }\end{array}$} & \multicolumn{3}{|c|}{ Consumo } & \multirow{2}{*}{$\begin{array}{c}\text { Poupança } \\
\text { em contra } \\
\text { corrente } \\
\text { (A) - (B) }\end{array}$} \\
\hline & & Pessoal & $\begin{array}{l}\text { Outras } \\
\text { compras } \\
\text { de bens } \\
\text { e serviços }\end{array}$ & $\begin{array}{c}\text { Consumo } \\
\text { Total } \\
\text { (B) }\end{array}$ & \\
\hline 1970 & 16,6 & 8,2 & 3,0 & 11,2 & 5,4 \\
\hline 1971 & 16,8 & 8,2 & 2,8 & 11,0 & 5,8 \\
\hline 1972 & 16,6 & 8,0 & 2,8 & 10,8 & 5,8 \\
\hline 1973 & 16,8 & 7,4 & 3,1 & 10,5 & 6,3 \\
\hline 1974 & 14,3 & 6,8 & 3,0 & 9,8 & 4,5 \\
\hline 1975 & 14,4 & 7,4 & 3,2 & 10,6 & 3,8 \\
\hline 1976 & 14,9 & 7,2 & 3,4 & 10,6 & 4,3 \\
\hline 1977 & 13,4 & 6,6 & 2,9 & 9,5 & 3,9 \\
\hline 1978 & 11,6 & 6,6 & 2,7 & 9,3 & 2,3 \\
\hline 1979 & 11,6 & 6,6 & 2,8 & 9,4 & 2,2 \\
\hline 1980 & 10,0 & 6,2 & 2,6 & 8,8 & 1,2 \\
\hline 1981 & 10,0 & 6,2 & 2,7 & 8,9 & 1,1 \\
\hline 1982 & 10,3 & 7,0 & 3,0 & 10,0 & 0,3 \\
\hline 1983 & 8,7 & 6,5 & 2,9 & 9,4 & $-0,7$ \\
\hline
\end{tabular}

Fonte: Contas Nacionais. Apud, WERNECK, 1986, p. 561. 


\section{Gráfico 6 - Consumo e poupança em conta corrente do governo - 1970/1983 (valores em percentagem do PIB)}

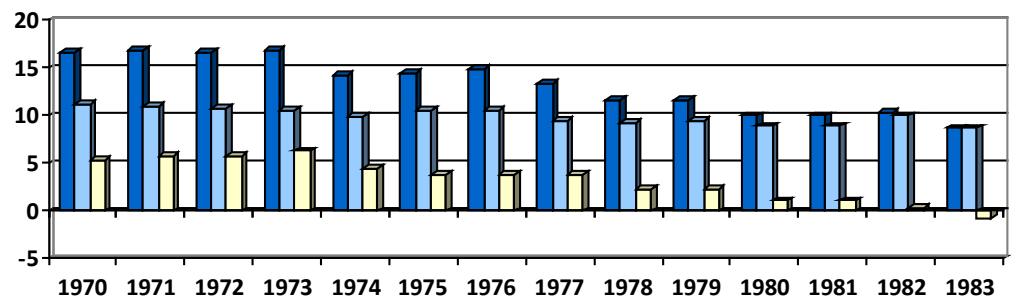

$\square$ Renda disponível do setor público $\square$ Consumo $\square$ Poupança em conta corrente

Fonte: Contas Nacionais. Apud, WERNECK, 1986, p. 561. Elaboração Própria.

A redução da renda disponível do setor público foi acompanhada pari passu pela diminuição da poupança em conta corrente do governo. Se entre 1970 e 1983 a renda disponível teve seus percentuais reduzidos a quase metade, passando de $16,6 \%$ para 8,7\%, a queda dos índices da poupança em conta corrente teve uma redução muito mais drástica. O índice positivo de 5,4\% de 1970 foi decrescendo ao longo da década e chegou ao patamar negativo de $0,7 \%$ em 1983.

O processo de endividamento externo das empresas estatais foi juridicamente viabilizado pela lei no. 4.331 de 1962 que definiu o cômputo das remessas através da exclusão do reinvestimento de lucros. A partir de 1964, os repasses e a captação direta facilitaram a entrada de empréstimos. Tanto as empresas públicas quanto as privadas viram na nova legislação uma possibilidade de financiamento: passaram a ter acesso a empréstimos de longo prazo, assim como a garantia de diferencial de custo (CAMPOS, 1990, p. 55). 


\section{Considerações finais}

O projeto privatista brasileiro, um dos mais importantes desdobramentos do ideário neoliberal que entra com força total no Brasil dos anos 1990, requer novos estudos e pesquisas mais consistentes, para que seus interstícios possam ser desnudados. Os argumentos naturalizados por boa parte da grande imprensa nacional e internacional e mesmo pela literatura especializada, carecem de sustentação empírica. O que estava em jogo então era a naturalização e construção de consenso em torno de um projeto que desqualificou o Estado brasileiro e, principalmente, o Setor Público Estatal, como uma estratégia de encorpar um discurso da necessidade de privatização das empresas nacionais como único caminho para reversão da crise econômica que o país atravessava. A hipótese aqui defendida acerca da crise das Empresas Estatais na década de oitenta como desdobramento das estratégias políticas e econômicas dos governos Geisel e Figueiredo caminhou exatamente nessa perspectiva de questionamento dos fundamentos discursivos do projeto privatista.

O olhar mais detalhado sobre o processo histórico que levou à implementação das principais resoluções da política econômica no pós-1964 possibilitou chegar à conclusão de que estas acabaram por definir os contornos da política industrial responsável pelo quadro de penúria da grande maioria do Setor Produtivo Estatal na década de oitenta. Muito mais do que os gastos com o funcionalismo público, a inoperância da burocracia e os constantes prejuízos das empresas que compunham o Setor Produtivo Estatal, argumentos alardeados então como responsáveis pela sangria dos cofres públicos e pelo crônico déficit público brasileiro, a crise das Empresas Estatais dos anos 1980 repousa sob outros fundamentos.

Dessa forma, procurou-se demonstrar que um dos grandes argumentos dos adeptos da onda privatista não se sustenta empiricamente. No cerne da referida crise, encontravam-se, essencialmente, o aumento exponencial dos encargos dos empréstimos estrangeiros contraídos pelas Empresas Estatais e a redução da renda disponível ao setor público, estratégias da política econômica dos governos 
militares, principalmente a partir do governo Geisel. As Empresas Estatais, assim, atuaram como ferramenta de controle inflacionário, em detrimento dos desdobramentos para sua saúde financeira.

No entanto, a despeito da fragilidade do principal argumento privatista, na constatação da falência das Empresas Estatais reside o cerne do projeto de privatização. Aqui no Brasil e alhures.

\section{THE RESTRUCTURING OF THE BRAZILIAN STATE PUBLIC SECTOR TOWARD THE 1990'S PRIVATIZATION}

Abstract: This paper has as its main object to examine the mechanisms that triggered the profound crisis of the Brazilian State-owned enterprises over the years 1980 opening space, thus, for the strengthening of privatista project implemented with great force in the years 1990. Part of the central hypothesis that the main arguments privatistas captained in the 1990 don't hold up empirically. Thus, the economic bankruptcy of sees have been slowly gestated from economic policy put in place in the years 1970, mainly from the II National Development Plan of 1974. For operationalization of the hypothesis here built will be investigated the main legal frameworks of privatista project implemented during the civil-military dictatorship, the reports of the Federal Council of Privatization and the National Development Bank (BNDES), principal manager of the privatization program.

Keywords: Privatization. State Enterprises. Economic Policy.

\section{Notas}

${ }^{1}$ Há um intenso debate entre os historiadores sobre a caracterização dos governos que chegaram ao poder, em abril de 1964, a partir da destituição do presidente João Goulart, democraticamente eleito. As interpretações variam entre "Ditadura de Segurança Nacional" (PADRÓS, 2007), regimes hegemonicamente controlados pelo militares (FICO, 2004; 2004(b); GORENDER, 1987) e "Ditadura Empresarial Militar" (DREIFUSS, 1987). Compartilha-se, aqui, da análise de René Dreifuss que, orientado teoricamente pelos escritos de Gramsci, e a partir de um exaustivo trabalho empírico, sustentou a hipótese de que no movimento que destituiu João Goulart houve uma intensa e determinante participação dos intelectuais orgânicos da classe dominante que, inseridos no complexo IPES/IBAD, foram determinantes não só na organização do golpe como também na montagem e condução da ossatura material do Estado que a partir de então passou a controlar o país. 


\section{A Reestruturação do Setor Público Estatal Brasileiro...}

2 Para uma discussão sobre o processo de abertura e a aprovação da Lei da Anistia, ver LEMOS, Renato, 2002 e SILVA, Francisco Carlos Teixeira da, 2009. 3 O "milagre econômico" é caracterizado como os elevados níveis de crescimento da economia brasileira entre o período de 1968 e 1973. Segundo Hermann (2005), o "milagre" fôra produto da combinação entre as vigorosas taxas de crescimento econômico, redução dos níveis inflacionários e eliminação dos déficits do balanço de pagamentos. Tal combinação teria sido viabilizada pelos seguintes elementos: i) existência de capacidade ociosa da economia; ii) considerável liquidez da economia internacional; iii) os instrumentos repressivos governamentais que reduziam a capacidade de reação diante das medidas governamentais; iv) a política de controle de preços e salários; v) os baixos juros; vi) a política deliberada de captação de recursos externos. Ver também PRADO, Luiz Carlos Delorme; SÀ EARP, Fábio, 2009.

${ }^{4} \mathrm{O}$ Ato Institucional $\mathrm{n}^{\mathrm{o}}$ 5, AI5, o mais famoso dos Atos Institucionais, foi redigido pelo Ministro da Justiça, Luís Antônio da Gama e Silva e entrou em vigor no dia 13 de dezembro de 1968, durante o governo do General Presidente Artur da Costa e Silva. Entre as medidas presentes no AI5, destacam-se o poder de intervenção do Presidente da República nos estados e municípios; a suspensão dos direitos políticos de quaisquer cidadãos por dez anos; a cassação de mandatos eletivos federais, estaduais e municipais; a decretação, pelo Presidente, do confisco de bens de todos quantos tenham enriquecido, ilicitamente, no exercício de cargo ou função pública, inclusive de autarquias, empresas públicas e sociedades de economia mista, sem prejuízo das sanções penais cabíveis; a suspensão da garantia de habeas corpus nos casos de crimes políticos contra a segurança nacional, a ordem econômica e social e a economia popular; o recrudescimento da censura prévia que se estendia à imprensa, à música, ao teatro e ao cinema. O AI5 chegou ao fim a partir da aprovação, em 13 de outubro de 1978, durante o Governo Geisel, da emenda constitucional n 11 que revogou todos os atos institucionais e complementares e entrou em vigor em 01 de janeiro de 1979. Para uma discussão sobre o significado do AI5 na estrutura de poder montada pela Ditadura Civil Militar, ver FICO, Carlos, 2004 (b).

${ }^{5} \mathrm{O}$ mais destacado exemplo dessa relação entre Atos Institucionais e medidas recessivas da política econômica é o PAEG (Programa de Ação Econômica do Governo). Implementado em 1964, sob a condução de Roberto Campos e Octávio Bulhões, o PAEG promoveu importantes mudanças na política econômica nacional como a criação do Banco Central e do Conselho Monetário Nacional. Sustentado pelo diagnóstico de que a inflação era gerada pelo excesso de demanda, o Programa impôs um severo corte das despesas governamentais, o controle do crédito ao setor privado e um mecanismo de correção salarial pelo qual as suas revisões deveriam ser determinadas pelo critério de manutenção 
do salário real médio verificado no biênio anterior, acrescido de porcentagem correspondente ao aumento de produtividade. Essa regra salarial foi aplicada inicialmente à administração pública e estendeu-se à iniciativa privada em 1966. (HERMANN, 2005, p. 69-92). Ver também PASTORE, Affonso Celso; PINOTTI, Maria Cristina, 2007.

${ }^{6}$ Para uma discussão sobre o Programa Nacional de Desestatização implementado nos anos 1990, ver PICCOLO, Monica, 2010 e CASTRO, Lavínia, 2005.

${ }^{7}$ A BNDESPAR, constituída em julho de 1982, atuara como sucessora das empresas Mecânica Brasileira S.A, EMBRAMEC, Financiamento e Participações de Insumos Básicos S.A., FIBASE e Investimentos Brasileiros S.A. e IBRASA, todas então subsidiárias do BNDE (atual BNDES). Criadas em 1975 no âmbito de uma política governamental, tinham como objetivo a promoção da capitalização da empresa privada nacional.

${ }^{8}$ DRME - sigla utilizada para se referir a depósitos registrados em moedas estrangeiras.

${ }^{9}$ A renda disponível do setor público é composta pela carga tributária bruta (impostos diretos e indiretos mais as outras receitas correntes líquidas do governo menos o que é devolvido ao setor privado na forma de subsídios e transferências) (WERNECK, 1986, p. 557).

\section{Referências}

BIASOTO JR, Geraldo. Dívida externa e desequilíbrio financeiro no setor público. Análise de Conjuntura. Belo Horizonte, n. 2. v. 1, jan./abr., 1987, p. 25-39. BRASIL. Decreto n 83.740 de 18 de julho de 1979. Institui o Programa Nacional de Desburocratização e dá outras providências. Diário Oficial [da] República Federativa do Brasil, DF, Brasília, Seção I, página 10109, 18 de julho de 1979.

. Decreto n 84.128, de 29 de outubro de 1979. Dispõe sobre o controle de recursos e dispêndios de empresas estatais e dá outras providências. Diário Oficial [da] República Federativa do Brasil, DF, Brasília, Seção I, página 15958, 30 de outubro de 1979.

. Decreto n 86.215, de 15 de julho de 1981. Fixa normas para a transferência, transformação e desativação de empresas sob o controle do Governo Federal, nos casos que especifica. Diário Oficial [da] República Federativa do Brasil, DF, Brasília, Seção I, página 13309, 16 de julho de 1981.

Decreto n 91.991, de 28 de novembro de 1985. Dispõe sobre o processo de privatização de empresas sob controle direto ou indireto do Governo

Anos 90, Porto Alegre, v. 21, n. 39, p. 363-397, jul. 2014 


\section{A Reestruturação do Setor Público Estatal Brasileiro...}

Federal, e dá outras providências. Diário Oficial [da] República Federativa do Brasil, DF, Brasília, Seção I, página 18509, 29 de novembro de 1985.

Decreto n. 95.886, de 29 de março de 1988. Dispõe sobre o Programa

Federal de Desestatização e dá outras providências. Diário Oficial [da] República Federativa do Brasil, DF, Brasília, Seção I, página 5837, 30 de março de 1988.

. Decreto n. 97.455, de 15 de janeiro de 1989. Dispõe sobre a prioridade, inclusões no Programa Nacional de Desestatização e designação do Gestor do Fundo Nacional de Desestatização. Diário Oficial [da] República Federativa do Brasil, Brasília, DF, Seção I, página 849, 16 de agosto de 1990.

Lei n. 6.151, de 4 de dezembro de 1974. II PND: II Plano Nacional de Desenvolvimento (1975-1979).

- Ministério do Planejamento. Plano Estratégico de Desenvolvimento (PED), 1976.

. Conselho Federal de Desestatização. Relatório (1984-1984).

. BNDES. Privatização. A experiência da BNDESPAR (1987-1989). Editado pelo Gabinete da Presidência do BNDES, Departamento de Relações Institucionais, abril de 1992.

. BNDES. Programa Nacional de Desestatização Edição Especial. Rio de Janeiro, IMF Editora, 1991.

. BNDES. Relatório de Atividades Sistema BNDES, 1990.

. BNDES. Relatório de Atividades Sistema BNDES, 1991.

BNDES. Programa Nacional de Desestatização. Relatório de Atividades Sistema BNDES, 1992.

CAMPOS, Adriana Fiorotti. O II PND e o processo de estatização da dívida externa: a crise das estatais e a sua posterior privatização. Raízes, ano XVIII, n. 19, maio, p. 49-64, 1999.

CASTRO, Lavínia Barros de. Esperança, Frustração e Aprendizado: a História da Nova República (1985-1989). In: GIAMBIAGI et al. (Orgs.). Economia brasileira contemporanea. Rio de Janeiro: Elsevier, 2005. p. 116-140.

DREIFUSS, René. 1964: a conquista do Estado. Ação política, poder e golpe de classe. Rio de Janeiro: Vozes, 1987.

FICO, Carlos. Versões e controvérsias sobre 1964 e a ditadura militar. Revista Brasileira de História. São Paulo, v. 24, nº 47, p. 29-60, 2004.

(b). Além do Golpe. Versões e controvérsias sobre 1964 e a Ditadura Militar. Rio de Janeiro: Record, 2004 


\section{Monica Piccolo Almeida}

GORENDER, Jacob. Combate nas Trevas. A esquerda brasileira: das ilusões perdidas à luta armada. São Paulo: Ática, 1987

HERMANN, Jennifer. Reformas, Endividamento Externo e o "Milagre Econômico" (1964-1973). In: GIAMBIAGI et al. (Orgs.). Economia brasileira contemporânea. Rio de Janeiro: Elsevier, 2005. p. 69-92.

(b). Auge e declínio do Modelo de Crescimento com endividamento: o II PND e a crise da dívida externa (1974-1984). In: GIAMBIAGI et al. (Orgs.). Economia brasileira contemporânea. Rio de Janeiro: Elsevier, 2005. p. 93-115.

LEMOS, Renato. Anistia e crise política no Brasil pós-1964. Topoi. Rio de Janeiro, dez., 2002. p. 287-313.

OLIVEIRA, Fabrício Augusto de. Política Econômica, Estagnação e Crise Mundial: Brasil, 1980-2010. Rio de Janeiro: Beco do Azougue, 2012

PADRÓS, Enrique Serra. América Latina: Ditaduras, Segurança Nacional e Terror de Estado. Revista História \& Luta de Classes, n 4, p. 43-49, jul. 2007.

PASTORE, Affonso Celso; PINOT'TI, Maria Cristina. O PAEG e as políticas econômicas dos anos 1960 e 1970. In: MOURA, Alkimar R. PAEG e Real: Dois planos que mudaram a economia brasileira. Rio de Janeiro: Editora FGV, 2007.

PICCOLO, Monica. Reformas Neoliberais no Brasil: A Privatização nos Governos Fernando Collor e Fernando Henrique Cardoso. Tese (Doutorado em História). Programa de Pós-Graduação em História da Universidade Federal Fluminense, Niterói, 2010.

PINHEIRO, Castelar; OLIVEIRA, Luiz. Privatização no Brasil: Passado, Planos e perspectivas. Texto para discussão IPE A, n: 230, ago. 1991. p. 1-51.

PRADO, Luís Carlos; SÁ EARP, Fábio. O “milagre” brasileiro: crescimento acelerado, integração internacional e concentração de renda (1967-1973). In: FERREIRA, Jorge; DELGADO, Licília (Orgs.). O Brasil Republicano. O tempo da ditadura. Regime militar e movimentos sociais em fins do século XX. Rio de Janeiro: Civilização Brasileira, 2003. p. 207-241.

WERNECK, Rogério L. Furquim. A questão do controle da necessidade de financiamento das empresas estatais e o orçamento de dispêndios globais da SETTT. Pesquisa de Planejamento da Economia. Rio de Janeiro, Departamento de Economia da PUC/RJ, n: 16, v. 3, ago. 1986. p. 381-412.

Recebido em: 02/08/2012.

Aprovado em: 04/09/2013. 
